\title{
Prognostic role of neuroendocrine differentiation in prostate cancer, putting together the pieces of the puzzle
}

This article was published in the following Dove Press journal:

Open Access Journal of Urology

22 July 2010

Number of times this article has been viewed

\author{
Alfredo Berruti' \\ Francesca Vignani' \\ Lucianna Russo' \\ Valentina Bertaglia' \\ Mattia Tullio' \\ Marcello Tucci' \\ Massimiliano Poggio² \\ Luigi Dogliotti' \\ 'Oncologia Medica, ${ }^{2}$ Urologia, \\ Dipartimento di Scienze Cliniche e \\ Biologiche, Università di Torino, \\ Azienda Ospedaliero Universitaria \\ San Luigi, Orbassano, Italy
}

\begin{abstract}
Neuroendocrine (NE) differentiation is a common feature in prostate cancer (PC). The clinical significance of this phenomenon is controversial; however preclinical and clinical data are in favor of an association with poor prognosis and early onset of a castrate resistant status. NE PC cells do not proliferate, but they can stimulate the proliferation of the exocrine component through the production of paracrine growth factors. The same paracrine signals may favor the outgrowth of castrate adapted tumors through androgen receptor dependent or independent mechanisms. Noteworthy, NE differentiation in PC is not a stable phenotype, being stimulated by several agents including androgen deprivation therapy, radiation therapy, and chemotherapy. The proportion of NE positive PC, therefore, is destined to increase during the natural history of the disease. This may complicate the assessment of the prognostic significance of this phenomenon. The majority of clinical studies have shown a significant correlation between NE differentiation and disease prognosis, confirming the preclinical rationale. In conclusion the NE phenotype is a prognostic parameter in PC. Whether this phenomenon is a pure prognostic factor or whether it can influence the prognosis by favoring the onset of a castrate resistance status is a matter of future research.
\end{abstract}

Keywords: prostate cancer, prognosis, neuroendocrine differentiation

\section{Introduction}

Neuroendocrine (NE) differentiation, that is usually determined by immunoreactivity for NE markers [eg, chromogranin A ( $\mathrm{CgA})$, neuron specific enolase (NSE)], is a common feature of prostatic adenocarcinomas. ${ }^{1-4}$ Pure NE prostate cancers (PCs), such as small cell cancers, are rare and aggressive tumors; primary carcinoids are less aggressive and exceptional. In most cancers, the NE component coexists in the context of the non-NE component. ${ }^{1}$ Theoretically, the spectrum of tumors having mixed divergent differentiation along NE and non-NE lineages could display a variable extension of the two components, potentially ranging from 1 to $99 \% .^{5}$ In the majority of PCs the NE component occupies a small portion of the tumor that does not exceed $5 \%$ of the overall tumor mass. ${ }^{1}$ Only occasionally does it exceed the quota of $30 \%{ }^{5}$ The clinical significance of the coexistence of the NE phenotype in the context of classic prostate adenocarcinoma is still controversial, but several examples of preclinical and clinical data have shown that this phenomenon is correlated with a poor prognosis and a greater chance of developing a castrate resistant status. ${ }^{2}$ In this paper, we review the biological rationale and the data supporting and not supporting the negative prognostic role of NE differentiation in prostate adenocarcinoma.
Correspondence: Alfredo Berruti Oncologia Medica,Azienda Ospedaliero Universitaria San Luigi, Regione Gonzole 10, 10043 Orbassano, Italy

$\mathrm{Tel}+39$ OII 90265 I2

$\mathrm{Fax}+390119026992$

Email alfredo.berruti@gmail.com 


\section{Origin of NE differentiation in PC}

Normal prostate glands harbor NE cells with the dual properties of endocrine cells and neurons that are widely distributed in normal prostatic acini and ducts. It is thought that these cells may have a regulatory role of the exocrine cells via a variety of secretory products. ${ }^{2}$

The origin of NE PC cells is not fully understood, but accumulated evidence has revealed that the biological characteristics of these cells are quite different from the normal NE prostate cells. ${ }^{6}$ Several dissimilarities have been observed: 1) immunohistochemical studies have shown that NE cells in the normal prostate gland express basal cell markers, while NE PC cells exhibit characteristics of luminal secretory cells; ;,7,8 2) NE cells from a normal prostate do not express anti-apoptotic $\mathrm{Bcl}-2$ protein, while studies in archival PCa samples show a correlative relationship between the expression levels of Bcl-2 and neuron-specific enolase; ${ }^{9}$ 3) $\alpha$-methylacyl-CoA racemase (AMACR), an enzyme involved in the $\beta$-oxidation of fatty acids, is expressed in NE PC cells, but not in non-NE prostate tumor cells nor in normal prostatic cells including NE cells. ${ }^{7}$ For this reason, the term 'NE-like' PC cell has been suggested to define this population of cancer cells. ${ }^{6}$

There are a number of theories that suggest a point of origin for these cells. ${ }^{10}$ One theory postulates that NE differentiation originates from neural crest cells, ${ }^{11,12}$ which give rise to cells containing neurosecretory granules known as 'amine precursor uptake decarboxylase'; another theory postulates that these cells could be the final dedifferentiation product of typical adenocarcinoma, based on a model of 'divergent differentiation'. ${ }^{13}$ This model suggests that NE cells might be derived from adenocarcinoma cells by a process of transdifferentiation, in response to microenvironmental changes in the hormonal and growth factor milieu. The finding that NE and exocrine tumor cells from radical prostatectomies share identical genetic profiles is consistent with this hypothesis. ${ }^{14}$

Recently, Palapattu et al have observed that in human PC cell lines, the expression of CD44, a marker of lymphocytes and cancer stem cells, is associated with cells of NE phenotype. ${ }^{15}$ In addition, NE tumor cells in human PC tissues were found to be virtually all positive for the CD44 antigen, and CD44 positive PC cells were all NE tumor cells. These results would suggest that NE cells may themselves represent the stem/progenitor cells for the bulk differentiated, secretory-type cancer cells. This interesting third hypothesis deserves confirmation.
Moreover, the NE differentiation in PC is not a stable phenotype. Existing evidence supports a model in which NE-like cells arise from prostate tumors following tumor cell exposure to one or more differentiation factors. ${ }^{6,16}$ Several in vitro experiments have demonstrated a transdifferentiation of PC cell lines into the NE phenotype in response to interleukin- $6,{ }^{17,18}$ AMP-inducing agents such as epinephrine, ${ }^{19,20}$ androgen deprivation, ${ }^{21}$ and genistein. ${ }^{22}$ With respect to the role of soluble cytokines in inducing NE differentiation, the mechanism may be more complex, involving the pleiotrophic activity of TGF- $\beta$ signaling pathway. ${ }^{23}$ The stimulation of prostate NE differentiation by androgen deprivation has been confirmed in vivo, either in the animal model ${ }^{24}$ or in humans. In patients with early PC, an increase of NE cells was shown in matched tumor samples collected before and after androgen deprivation therapy (ADT) administered in a neoadjuvant setting. ${ }^{25}$ While in patients with advanced disease, increased $\mathrm{CgA}$ serum levels were repeatedly observed after androgen deprivation therapy. ${ }^{26,27}$

The stimulatory effect of the NE phenotype by androgen deprivation accounts at least in part in the NE cell enrichment observed in the castrate resistant disease. ${ }^{28,29}$

Moreover, it has been repeatedly observed that prostate adenocarcinomas with NE differentiation can change phenotype during androgen deprivation, acquiring characteristics of small cell carcinoma and therefore becoming castrate resistant..$^{30,31}$ These data are consistent with an unstable phenotype of PC with NE differentiation under androgen deprivation.

Androgen deprivation therapy, however, is probably not the only antineoplastic therapy that can modulate NE differentiation. An in vitro study has recently observed that fractionated ionizing radiation (IR) induces differentiation of lymph node carcinoma of prostate (LNCaP) PC cells into NE-like cells. ${ }^{32}$ In a further in vivo study performed in the transgenic adenocarcinoma of mouse prostate (TRAMP) model, chemotherapy with docetaxel was able to induce NE differentiation, and the incidence of this phenomenon was similar to that obtained with androgen deprivation. ${ }^{33}$ Interestingly, the combination of both therapies, that is commonly employed in castrate resistant patients, was synergistic in inducing the NE phenotype. ${ }^{33}$ Noteworthy, $\mathrm{NE}$ transdifferentiation in vitro is a reversible phenomenon, meaning that NE PC cells can potentially lose the NE phenotype upon withdrawal of inducing agents. ${ }^{34}$

The signaling pathways involved in the NE differentiation of PC are not fully understood. Wu and Huang demonstrated 
that the PI3K-AKT-mTOR pathway is critically involved in this process. ${ }^{35}$

An essential role of the Notch signaling pathway, and specifically of hASH1 (human achaete-scute homolog-1 transcription factor), has been reported in determining the NE phenotype of normal and neoplastic tissues. ${ }^{36-42}$ Our group has recently observed that hASH1 is also a critical factor involved in NE differentiation in PC, with special reference to patients treated with androgen-deprivation therapy. ${ }^{43}$

Mori et al evaluated the effect of various NE differentiationinducing factors on the gene signature of LNCaP cells in vitro, using GeneChip ${ }^{\circledR}$ (Affymetrix, Santa Clara, CA) arrays. ${ }^{44}$ They observed that, despite some overlap, each NE transdifferentiation inducing treatment was associated with a changed expression of a unique set of genes. This observation adds complexity in the molecular mechanisms involved in the NE transdifferentiation process seen in PC.

\section{Mechanisms by which NE differentiation can influence the prognosis of prostate adenocarcinoma}

Prostate adenocarcinoma with marked NE differentiation tends to be poorly differentiated and more aggressive. Several studies have shown that NE differentiation in PC samples and serum chromogranin A levels directly correlate with a greater stage and Gleason score, but not with serum prostate-specific antigen (PSA). ${ }^{45-48}$ In a study exploring the prognostic role of gene profiling expression, chromogranin A was found to be one of the five genes that were reported to serve as outcome predictors for tumor recurrence. ${ }^{49}$

In a paper by Tarle et al the acquirement of $\mathrm{NE}$ differentiation during maximal androgen blockade in PC patients was associated with an increased incidence of bone metastases. ${ }^{50}$

Noteworthy, neoplastic NE cells do not show evidence of cell proliferation. Bonkhoff et al have repeatedly demonstrated that NE PC cells lack the proliferation-associated Ki67 antigen. ${ }^{51,52}$ These data suggest that the aggressiveness of PC with marked NE features cannot be explained by cell kinetic properties of the endocrine component.

NE PC cells produce a variety of neuropeptides and biogenic amines such as cholecystokinin (CCK), bombesin, gastrin-releasing peptide, histamine, neuropeptide Y, parathyroid hormone-related protein, proadrenomedullin N-terminal peptide, serotonin, thyroid stimulating hormone-like peptide; most of them are notorious growth factors for neoplastic cells. ${ }^{2}$ An interesting hypothesis, depicted in Figure 1, is that NE PC cells can stimulate the non-NE component via paracrine and endocrine signals, thus making the exocrine component more aggressive. Consistent with this hypothesis is the greater Ki67 expression observed in exocrine PC cells close to NE cells, as opposed to their counterpart. ${ }^{51,52}$ In addition, it has been observed that NE PC cells can produce vascular endothelial growth factor $(\mathrm{VEGF})^{53-55}$ and the anti-apoptotic substance, survivin. ${ }^{56}$ A higher density of microvessels, in fact, has been observed around nests of NE cells compared to areas of PC with no signs of NE differentiation. ${ }^{53,54}$ Also hypoxia-inducible factor- $1 \alpha$ (HIF-1 $\alpha)$, one of the major transcription factors which has been shown to upregulate the expression of VEGF in response to tissue hypoxia, was recently identified in a subset of benign and malignant prostate NE cells. ${ }^{57}$

The overexpression of Bcl-2 proto-oncogene involved in apoptosis is highly correlated with cancer progression and androgen independence. It has been revealed that malignant cells that express $\mathrm{Bcl}-2$ are localized in close proximity to NE tumor cells. ${ }^{58}$ All these data suggest that the poor prognostic significance associated to the NE differentiation implies a complex interplay between the NE and exocrine component of PC.

\section{NE differentiation and resistance to androgen deprivation}

Cumulative evidence suggests that NE differentiation of $\mathrm{CaP}$ may be a cofactor involved in tumor progression and androgen independence.

Characteristics of the NE PC cells intermixed with a predominance of non-NE cells are the lack of detectable androgen receptor (AR) and PSA gene expression, genes that are otherwise highly expressed in prostate epithelial cells with secretory functions regulated by androgens. ${ }^{59,60}$ NE PC cells therefore cannot be modulated by androgen deprivation therapy.

Various mechanisms have been postulated to account for the conversion of exocrine adenocarcinoma of the human prostate $(\mathrm{CaP})$ into a castration-resistant state, the emerging theme is that the tumor is still dependent on AR signaling. The proposed mechanisms that explain continued AR signaling include AR gene amplification, resulting in a response to low levels of circulating androgens, the local synthesis/concentration of androgens, AR mutations that allow activation by antiandrogens or weak androgens, AR activation by growth factors/kinase pathways, and/or changes in AR coregulators. ${ }^{61}$ 


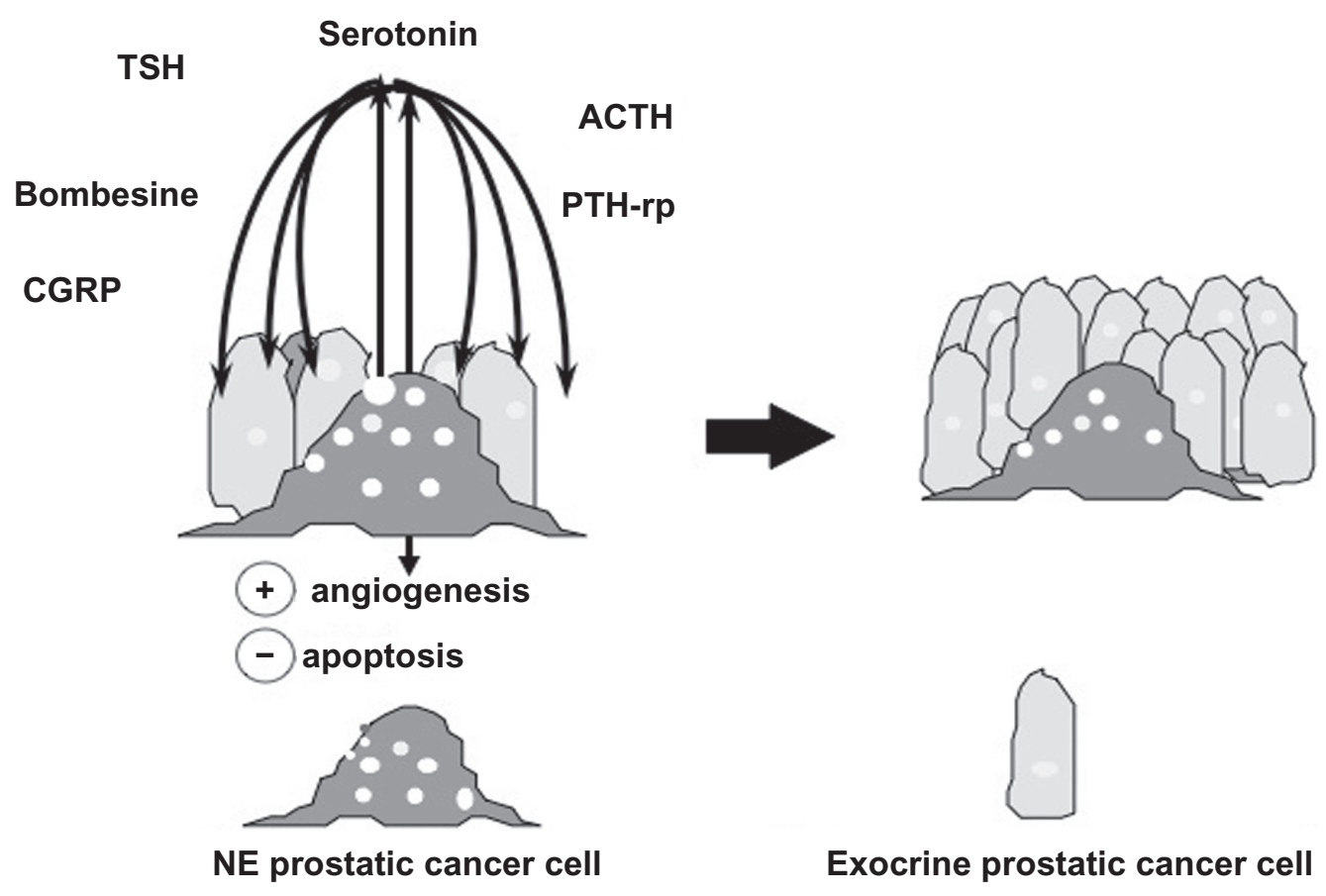

Figure I Neuroendocrine prostate cancer cells can stimulate the proliferation of non-neuroendocrine prostate cancer cells via paracrine and endocrine signals. Abbreviations: TSH, thyroid stimulating hormone; CGRP, calcitonin gene-related peptide; ACTH, adrenocorticotrophin; PTHrP, parathyroid hormone-related protein; $\mathrm{NE}$, neuroendocrine.

The question is how NE differentiation can interfere with these mechanisms.

It has been shown that $\mathrm{NE}$ secretory proteins can activate the NF- $\kappa B$ pathway in PC cells, and activation of NF- $\kappa B$ signaling is sufficient to maintain androgen-independent growth of PC via regulation of AR action. ${ }^{62}$

A paper recently published has shown that neuropeptides can transmit their signals through $\mathrm{G}$ protein-coupled receptors, which are often overexpressed in PC, and aberrantly activate the $\mathrm{AR}$ in the absence of androgens. ${ }^{63}$ The authors developed an autocrine neuropeptide model by overexpressing gastrin related peptide (GRP) (one of the most studied neuropeptides in prostate carcinoma) in LNCaP cells, and the resultant cell line, LNCaP-GRP, exhibited androgenindependent growth with enhanced motility in vitro. When orthotopically implanted in castrated nude mice, LNCaPGRP produced aggressive tumors, which expressed GRP, prostate-specific antigen, and nuclear-localized AR. Chromatin immunoprecipitation studies of LNCaP-GRP clones suggested that GRP activates and recruits AR to the cognate promoter in the absence of androgen.

On the basis of these data we can postulate that NE PC cells may contribute to the outgrowth of 'castration-adapted' tumors via the production of paracrine signals that interact with the exocrine PC cells by AR dependent or independent mechanisms.
One interesting paper provides a direct demonstration of this theory. ${ }^{16}$ In this study, LNCaP cells were engineered to induce acquisition of NE-like characteristics and loss of mitotic activity. Clonal NE cells enhanced the growth of prostate tumor cells in anchorage dependent and anchorageindependent in vitro assays as well as the growth of prostate tumor xenografts in vivo, with the greatest effects seen under conditions of androgen deprivation. ${ }^{16}$ This elegant study confirms that NE-like cells of prostatic tumors have the potential to enhance androgen independent tumor growth in a paracrine manner, thereby contributing to progression of the disease particularly in the androgen deprivation condition.

As previously mentioned, NE differentiation in PC is destined to increase during androgen deprivation therapy, and this phenomenon could enhance the onset of a castrate resistant phase as depicted in Figure 2.

Finasteride is a 5-alpha reductase inhibitor that leads to an intraprostatic dihydrotestosterone depletion. A recent explorative paper has shown that finasteride administered to patients with prostate hypertrophy was able to favor elevation of circulating CgA serum levels. ${ }^{64}$ In the PC prevention trial (PCPT), finasteride administered to healthy men was able to reduce the risk of PC by $25 \%$ with respect to placebo, but with an apparent increased risk of high-grade disease. ${ }^{65}$ Even though an update of this study failed to confirm a significant difference in the proportion of high grade disease between the 


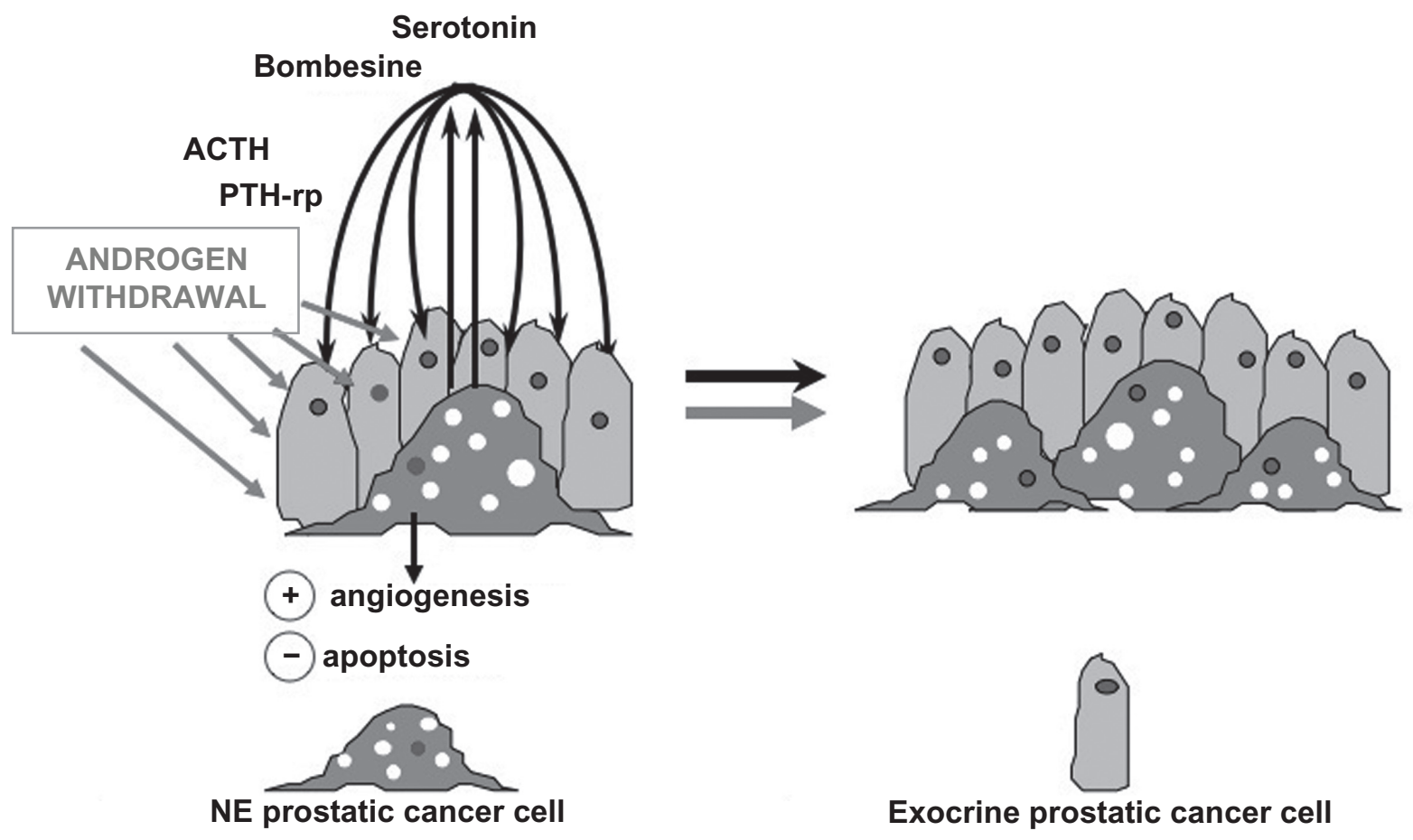

Figure 2 Androgen deprivation therapy stimulates the neuroendocrine differentiation, thus amplifying the negative interaction with the non-neuroendocrine compartment. Abbreviations: ACTH, adrenocorticotrophin; PTHrP, parathyroid hormone-related protein; NE, neuroendocrine.

two study arms, ${ }^{66}$ these data cannot exclude that in a patient subset, ie, patients destined to develop a NE phenotype, the administration of finasteride could have been detrimental. In a small randomized placebo controlled neoadjuvant trial, finasteride administration, was in fact able to decrease the apoptotic factor caspase $3,{ }^{67}$ it would be interesting to know whether this phenomenon was associated or not to a development of a NE phenotype.

\section{Clinical data}

The first paper showing the frequent elevation of circulating chromogranin levels in PC patients with castrate resistant metastatic disease was published in 1991 by Kadmon et al. ${ }^{68}$ Twelve out of 25 (48\%) patients enrolled had elevated CgA levels. These results were subsequently confirmed by other authors, ${ }^{63,70}$ and $\mathrm{CgA}$ is actually considered the best circulating marker for detecting and monitoring the NE differentiation in $\mathrm{PC}$.

Two papers have explored the prognostic role of NE differentiation, assessed by circulating $\mathrm{CgA}$, in PC patients with castrate resistant disease. The first one is a single institution experience, ${ }^{26}$ the second one refers to a data set of patients enrolled in a multicenter prospective clinical trial of the South West Oncology Group (SWOG).$^{71}$ As outlined in Table 1, both studies uniformly showed that elevated $\mathrm{CgA}$ levels were significantly correlated with a poor prognosis. It is interesting to note that in multivariate analysis after adjustment for commonly recognized prognostic factors (such as hemoglobin, albumin, lactate dehydrogenase [LDH], alkaline phosphatase) the hazard ratio (HR) of death from elevated $\mathrm{CgA}$ values was superimposable in both studies (close to 1.2).

Eighteen studies have explored the significance of NE differentiation in hormone naïve patients (Tables 2 and 3). ${ }^{72-89}$ Twelve studies enrolled patients with nonmetastatic disease (T1-4, N0 or N1) that were eligible for radical prostatectomy. ${ }^{73-76,78-82,86,87,89}$ In two of these studies one half of patients enrolled received neoadjuvant hormone therapy before surgery. ${ }^{73,86}$ One study enrolled patients with T1-4, N0-1 PC who underwent radiation therapy only. ${ }^{85}$ The remaining five studies were performed on patients with all stages of disease submitted to heterogeneous treatments (two papers), ${ }^{72,77}$ or included metastatic patients who underwent ADT (three papers). ${ }^{83,84,88}$

NE differentiation was assessed immunohistochemically in tumor specimens from radical prostatectomy in 11 papers, ${ }^{72-75,78-82,86,89}$ in 2 of them this phenotype was also assessed in abdominal lymphnodes. ${ }^{74,86}$ In three papers NE differentiation was assessed on prostate biopsies, ${ }^{65,72,77}$ while in two papers it was assessed on transurethal resection of the prostate (TURP) specimens (in one of them after a pretreatment with hormone therapy). ${ }^{77,84}$ In the remaining two papers, circulating $\mathrm{CgA}$ was employed instead of tissue evaluation. ${ }^{85,87}$ 
Table I Prognostic role of chromogranin A serum levels in castrate resistant prostate cancer

\begin{tabular}{|c|c|c|c|c|c|c|}
\hline Ist Author & $\begin{array}{l}\text { No. of } \\
\text { patients }\end{array}$ & $\begin{array}{l}\text { Stage of } \\
\text { disease }\end{array}$ & $\begin{array}{l}\text { Follow-up } \\
\text { time }\end{array}$ & $\begin{array}{l}\text { Median overall } \\
\text { survival (univariate } \\
\text { analysis) }\end{array}$ & $\begin{array}{l}\text { Overall survival all } \\
\text { cause of death: } \\
\text { (multivariate analysis) }\end{array}$ & $\begin{array}{l}N^{a} \\
\text { assessment }\end{array}$ \\
\hline $\begin{array}{l}\text { Berruti } \\
2005^{26}\end{array}$ & 108 & $\begin{array}{l}\text { Hormone- } \\
\text { refractory } \\
\text { disease }\end{array}$ & $\begin{array}{l}\text { Median } \\
72 \text { months }\end{array}$ & $\begin{array}{l}\text { Supranormal } \mathrm{CgA}^{\mathrm{b}} \\
\text { levels: } \\
\text { 10.2 months } \\
\text { Normal } \mathrm{CgA} \text { levels: } \\
22.6 \text { months } \\
P=0.0002\end{array}$ & $\begin{array}{l}\text { Supranormal CgA } \\
\text { levels: } \\
\text { HR: }^{c} \text { I.20 }\left(95 \% \mathrm{Cl}^{\mathrm{d}}\right. \\
0.99-1.44), P=0.05\end{array}$ & $\begin{array}{l}\text { Serum } \mathrm{CgA} \text { levels } \\
\text { at the onset } \\
\text { of hormone } \\
\text { refractory disease }\end{array}$ \\
\hline $\begin{array}{l}\text { Taplin } \\
2005^{71}\end{array}$ & 321 & $\begin{array}{l}\text { Metastatic } \\
\text { hormone- } \\
\text { refractory } \\
\text { disease }\end{array}$ & $\begin{array}{l}\text { Median } \\
35 \text { months }\end{array}$ & $\begin{array}{l}\text { Serum } \mathrm{CgA}>12 \\
\text { U/l: } I 1 \text { months } \\
\text { Serum } \mathrm{CgA} \leq 12 \\
\text { U/l: } 17 \text { months } \\
P=0.01 \\
\text { Serum } \mathrm{CgA}>9.5 \\
\text { U/l: } 12 \text { months } \\
\text { Serum } \mathrm{CgA}<9.5 \\
\text { U/l: } 18 \text { months } \\
P=0.021\end{array}$ & $\begin{array}{l}\text { Serum } \mathrm{CgA}>12 \mathrm{U} / \mathrm{l} \text { : } \\
\text { HR I.214 }(95 \% \mathrm{Cl} \\
0.967-1.525) \\
P=0.0952 \\
\text { Serum } \mathrm{CgA}>9.5 \mathrm{U} / \mathrm{l} \text { : } \\
\text { HR: } 1.326(95 \% \mathrm{Cl} \\
\text { I.045-I.683), } \\
P=0.0203\end{array}$ & $\begin{array}{l}\text { Serum CgA levels } \\
\text { at the onset of } \\
\text { hormone } \\
\text { refractory disease }\end{array}$ \\
\hline
\end{tabular}

Abbreviations: a $\mathrm{NE}$, neuroendocrine; ${ }^{\mathrm{b}} \mathrm{CgA}$, chromogranin $\mathrm{A}$; ${ }^{\mathrm{c}} \mathrm{HR}$, hazard ratio; ${ }^{\mathrm{d}} \mathrm{Cl}$, confidence interval.

As a whole the prognostic role of NE differentiation, assessed on baseline conditions, have led to controversial results. However these studies suffer from several limitations in terms of statistical power, primary prognostic end-point chosen and patient selection. Most of these studies have recruited a limited number of patients: seven studies, in fact, involved less than 100 patients, ${ }^{72,77,78,81,83,84,88}$ nine studies between 100 and 200 patients, ${ }^{73-76,79,80,85,86,89}$ while only two studies considered more than 200 patients. ${ }^{82,87}$ Due to the low potency of the majority of studies it is not surprising that many of them have led to inconclusive results.

The prognostic end point was time to progression in 10 studies, ${ }^{72,73,75,79,80,82,84,85,87,89}$ while overall survival was considered in only 8 studies. ${ }^{74,76,77,78,81,83,86,88}$ In most studies it was the time of PSA progression that was tested, which is actually considered a questionable end point. ${ }^{90}$ As a matter of fact in one study in which both time to PSA progression and time to clinical disease progression were concomitantly assessed, NE phenotype appeared prognostic in terms of time of clinical progression but not in terms of PSA progression. ${ }^{80}$

Another important issue is patient selection, most studies recruited patients eligible for radical prostatectomy. This patient population, due to low stage and grade, is destined per se to a good prognosis even without treatment and it is therefore not representative of the entire PC population.

These limitations notwithstanding, the prognostic significance of NE phenotype was observed in 10 studies (Table 2), ${ }^{80-89}$ whereas in eight papers NE differentiation failed to be prognostic (Table 3)..$^{72-79}$
If we look at the nonsignificative studies (Table 3), however, the prognostic significance of NE differentiation was found to be truly negative in three studies only. Bostwick et al including 196 patients with node positive carcinomas who underwent radical prostatectomy plus lymphadenectomy, showed superimposable disease-free survival rates and overall survival by comparing patients with immunohistochemical NE differentiation to patients without: HR 0.94 and 1.02, respectively. ${ }^{74}$ In a further study, Nordzij et al examined 90 patients who underwent radical prostatectomy and were followed for 86 months on average. The results showed that the presence of NE features was associated with a similar disease-free and overall survival prospect as compared with the absence of this phenotype. ${ }^{78}$ In contrast to all published studies, Veltri et al showed that the presence of NE differentiation correlated with a tendency toward a better prognosis in terms of disesase-free survival that just failed to attain the statistical significance $(P=0.12) .{ }^{79}$ In the remaining five papers, NE differentiation was associated with a tendency toward a poorer prognosis that failed to attain statistical significance, probably due to the low potency of these studies. ${ }^{72,73,75-77}$

In the study by McWilliams et al the prognostic role of NE differentiation attained the statistical significance in univariate but not in multivariate analysis. ${ }^{77}$

The 10 papers in which NE differentiation was found to be prognostic comprised patients submitted to radical prostatectomy for early disease (six papers), ${ }^{80-82,86,87,89}$ locally advanced or metastatic disease addressed to ADT(three papers), ${ }^{83,84,88}$ 


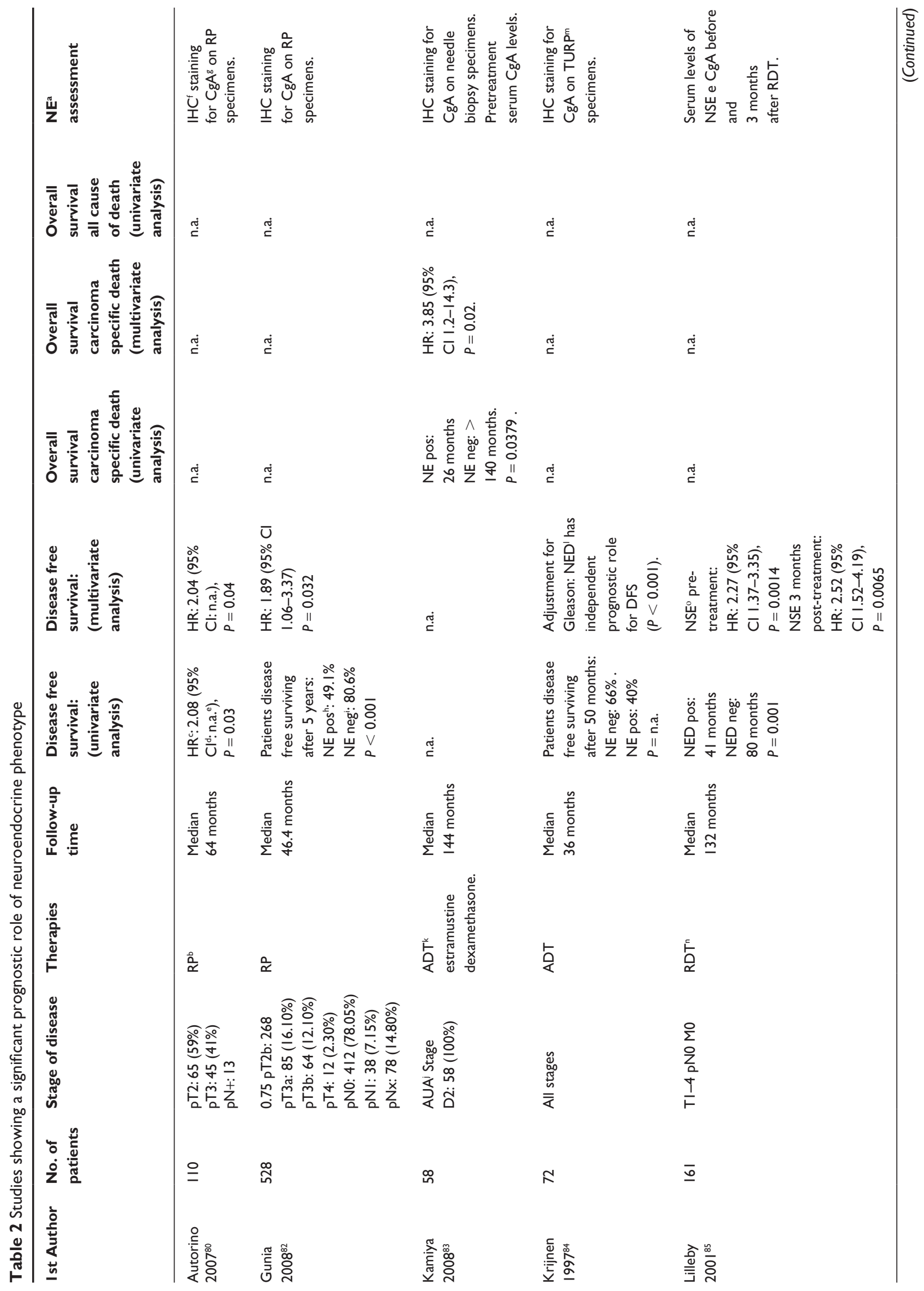




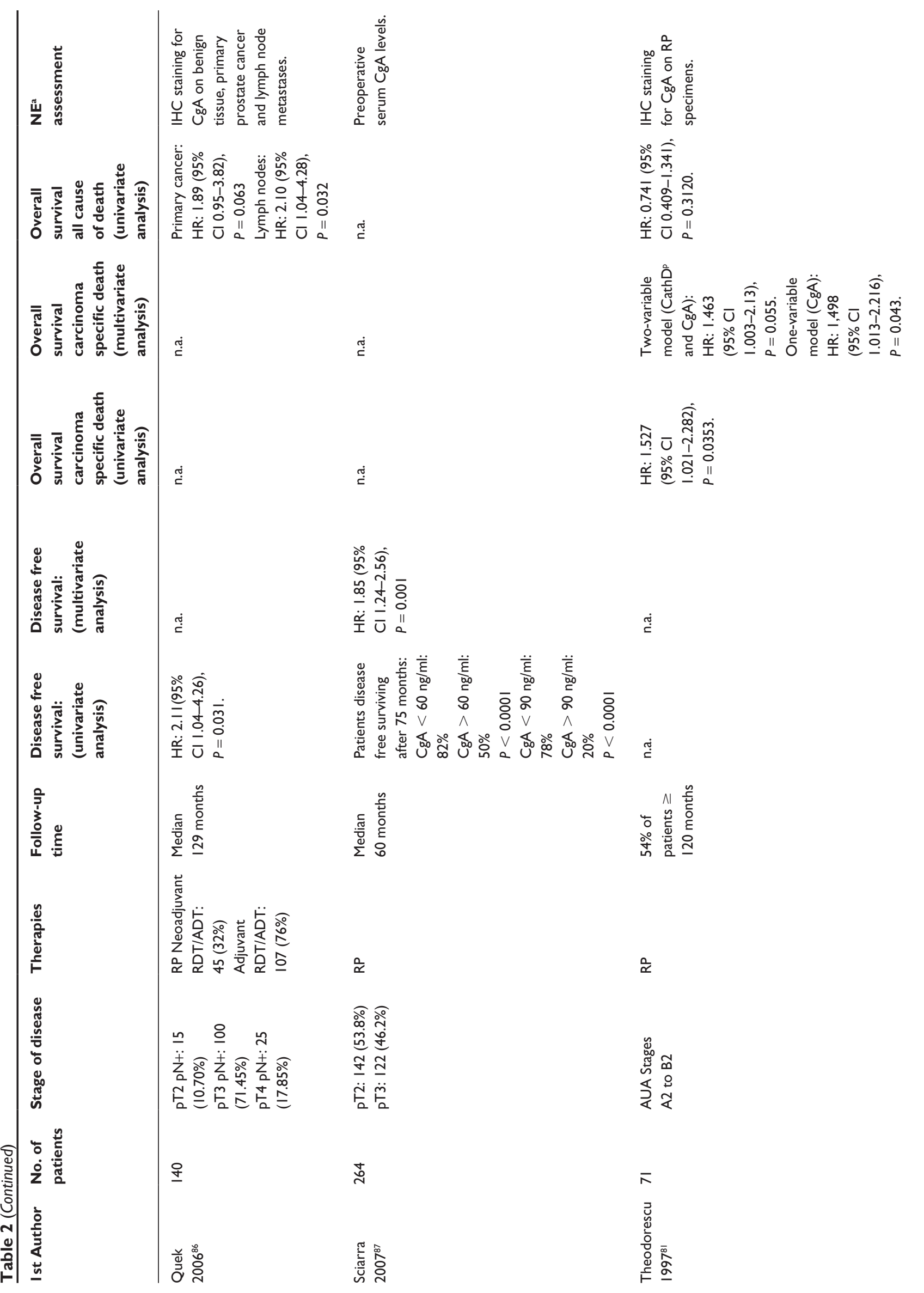




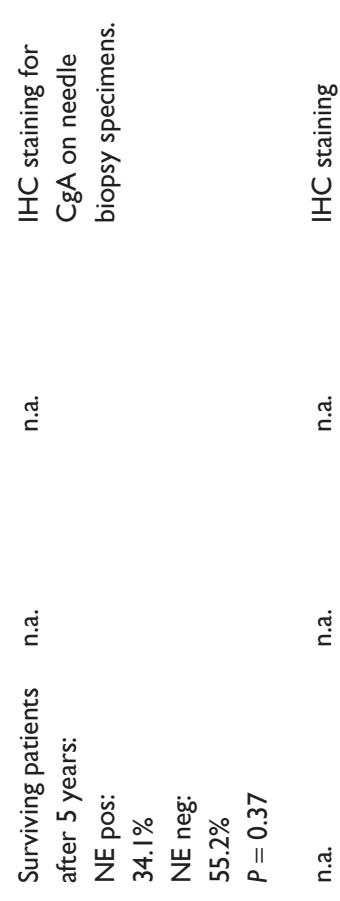

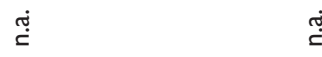

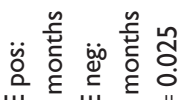

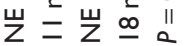

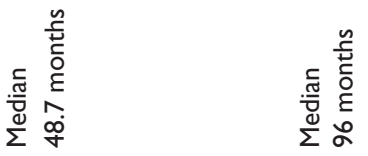

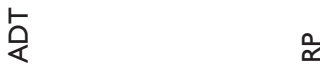

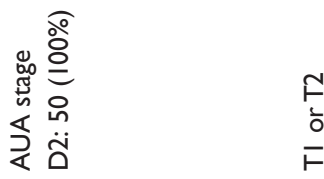

오

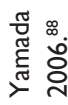

$\stackrel{t}{\underline{0}}$

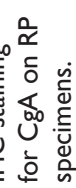

(n)

\section{(1)}

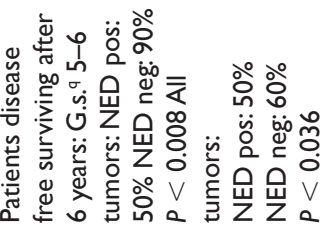

$\hat{x}$

$\frac{\mathfrak{c}}{\mathfrak{L}}$

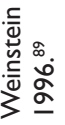

and patients who underwent radiation therapy only (one paper).$^{85}$ In six papers the prognostic significance was assessed in terms of time to progression, ${ }^{80,82,84,85,87,89}$ in four papers survival was also considered..$^{81,83,86,88}$ In nine papers $\mathrm{NE}$ differentiation was assessed by $\mathrm{CgA}$ expression, either at immunohistochemistry or in the general circulation. ${ }^{80-84,86-89}$ In one paper both circulating NSE and CgA were evaluated. ${ }^{85}$ Noteworthy, in this latter study, elevated serum NSE but not elevated serum $\mathrm{CgA}$ showed a prognostic significance.

\section{Our personal experience}

We have investigated the prognostic role of NE differentiation assessed on PC biopsies in 414 PC patients consecutively treated and followed at the PC unit of the Azienda Ospedaliero-Universitaria San Luigi Gonzaga, Orbassano, Italy. The median follow-up was 85 months. Two hundred and fourteen patients received ADT within the first 2 months of diagnosis in addition to local regional therapies (radiation therapy or radical prostatectomy) if indicated, 200 patients were submitted to local regional therapies alone. Since ADT stimulates NE differentiation, CgA plasma levels were determined at baseline condition and subsequently every year for 2 years in the patient subset immediately addressed to such a therapy. The results of this study were published in two different papers and are summarized in Table 4..$^{91,92}$

In multivariate analysis, after adjustment for age, stage, serum PSA, Gleason score and treatment administered (hormone therapy, radical prostatectomy, radiation therapy), NE differentiation assessed on baseline PC biopsies was prognostic in overall population in terms of overall survival (HR $1.56,95 \%$ Confidence Interval [CI] 1.12-2.17, $P=0.009$ ) but not in terms of PSA progression (HR 1.25, 95\% CI 0.96-1.62, $P=0.10$ ). However, dividing patients according to whether they received early androgen deprivation or not, the prognostic significance of NE differentiation, either in terms of disease-free survival or overall survival, appeared to be confined to the first patient subset. A significant prognostic interaction between $\mathrm{ADT}$ and tissue $\mathrm{CgA}$ expression was found in multivariate analysis in terms of time to progression, but not in terms of overall survival. It should be noted, however, that the majority of patients initially not submitted to ADT received this treatment after disease recurrence and this represents a confounder that may have accounted for the observed no interaction in terms of survival.

In the patient subset immediately addressed to androgen deprivation, elevated serum $\mathrm{CgA}$ was significantly associated with a poor prognosis in terms of progression-free survival and overall survival. These data paralleled the prognostic 


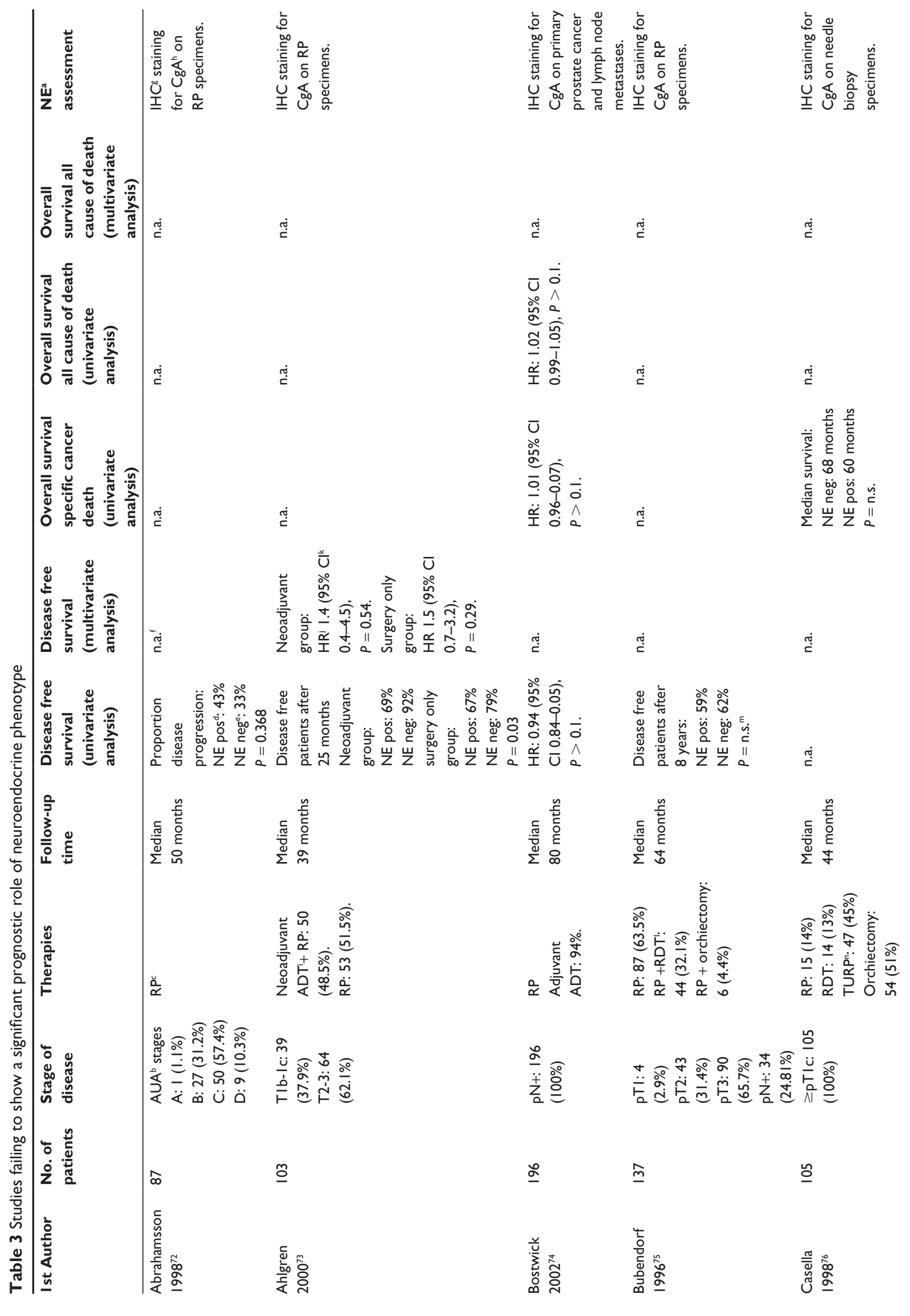



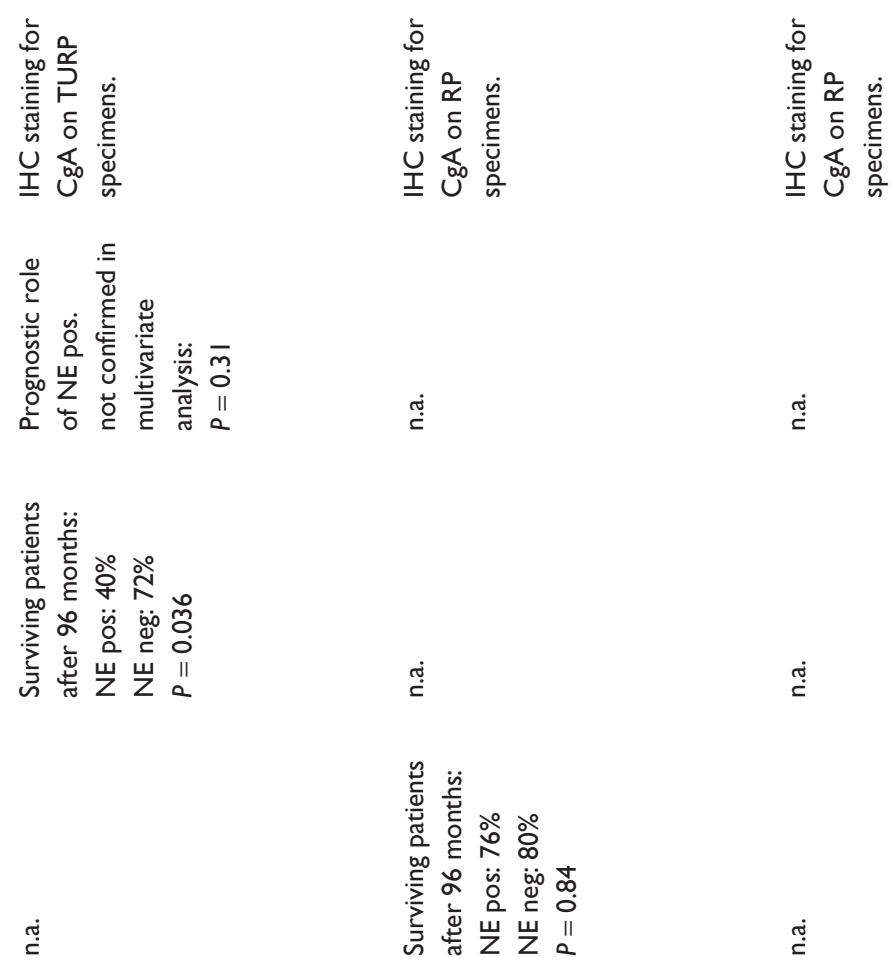

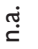

வே்

密岕岩崖 II

ฮேं

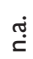

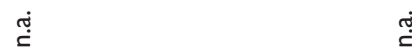

$\stackrel{\text { త্் }}{ }$

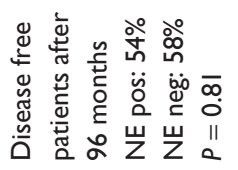

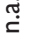

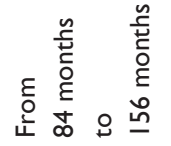

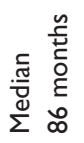

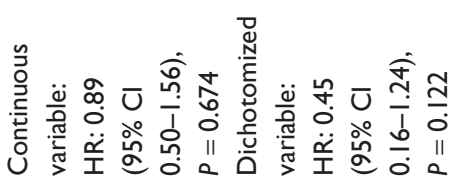

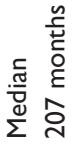

$\stackrel{\text { வ் }}{\dot{2}}$

$\stackrel{0}{\alpha}$

$\stackrel{9}{\alpha}$

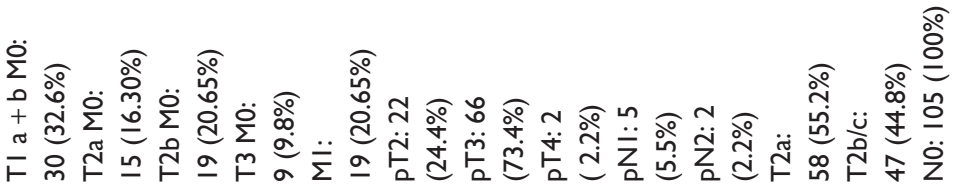

2

\&

능

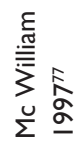

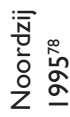

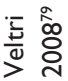




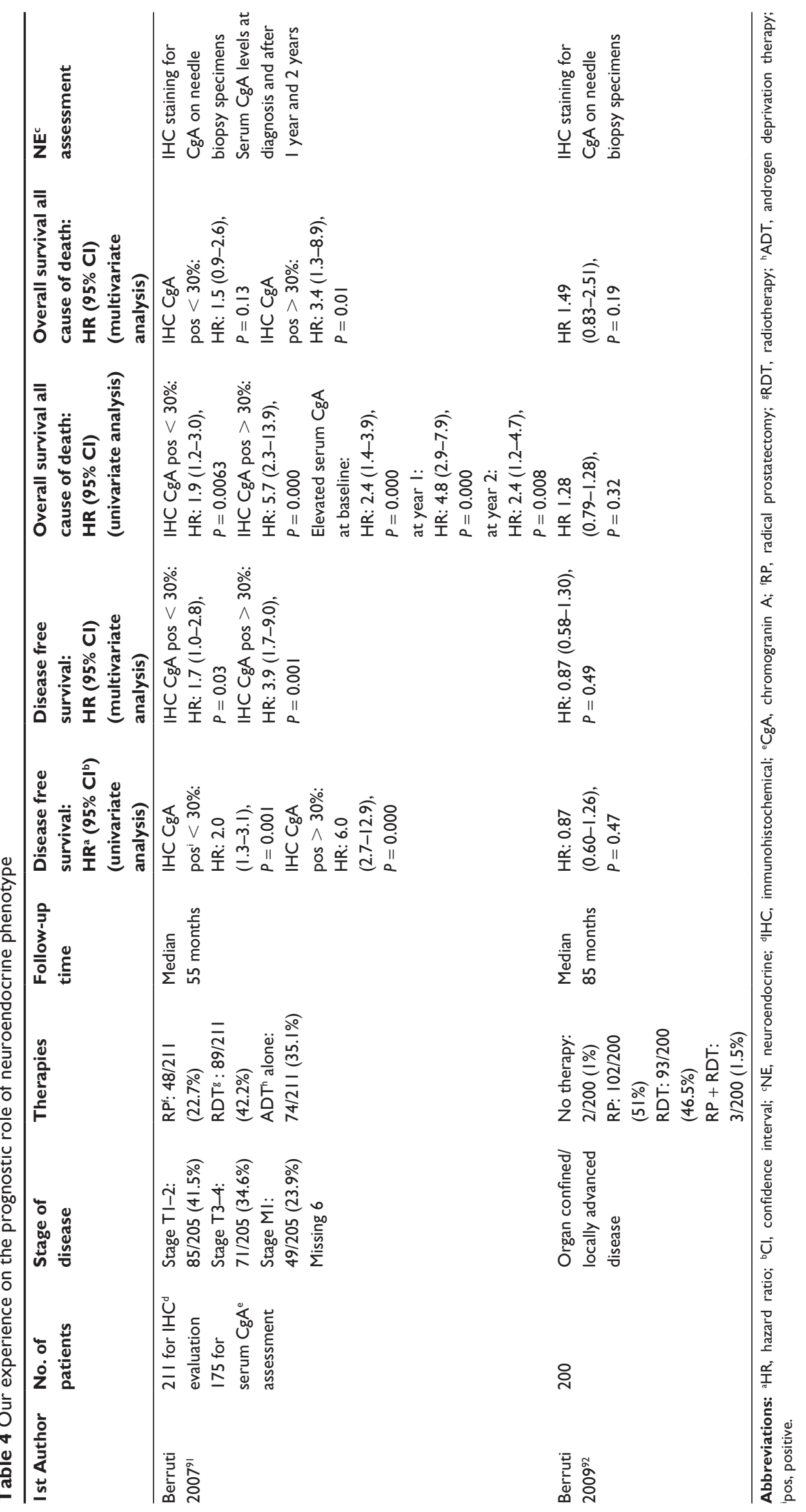


results obtained with the immunohistochemical $\operatorname{CgA}$ evaluation.

As expected, the proportion of patients with elevated serum CgA increased over time, being 20\% at baseline, $25 \%$ after one year and 35\% after two years.

Interestingly, the prognostic significance of elevated serum $\mathrm{CgA}$ levels was maintained at every time point. Since the patients with increased $\mathrm{CgA}$ at each point were not the same ones showing increased $\mathrm{CgA}$ at baseline, these data suggest that increasing $\mathrm{CgA}$ during ADT may be a signal of changed tumor biology toward a greater aggressiveness and resistance to endocrine therapy. ${ }^{91}$

\section{NE differentiation as a target for specific molecular target agents}

Since the postulated mechanisms by which NE differentiation enhances the aggressiveness of PC is the paracrine stimulation of the exocrine component of the tumor, there is a rationale for the clinical use of somatostatin analogs that are notoriously able to inhibit the synthesis of neusecretory products.

Few data exist about the selected antiproliferative effect of somatostatin in preclinical model systems. An in vitro study has shown that somatostatin is able to reduce the proliferation of LNCaP cells. ${ }^{93}$ In a further study adjuvant therapy with lanreotide was found effective in slowing cancer growth in castrated Copenhagen rats bearing Dunning R-3327-H prostate tumors. ${ }^{94}$

In an elegant in vitro study recently published, Ruscica and coworkers investigated the effects of lanreotide and new mono- and bi-specific somatostatin agonists on proliferation and secretory pattern of the insulin growth factor (IGF) system in LNCaP cells, a model of androgen-dependent PC. ${ }^{95}$ They found that all these somatostatin analogs have an antiproliferative effect against LNCaP PC cells. This antiproliferative activity, mediated by an induction of p27 and p21 cell-cycle inhibitors and a down-regulation of protein expression of cyclin E, was counteracted by the coincubation with a somatostatin receptor subtype-2 (sst2) antagonist. These data suggest a role for the sst 2 receptor in mediating this effect. All somatostatin analogs caused a significant reduction in IGF-I and IGF-II secretion. Noteworthy, the administration of exogenous IGF-I counteracted the inhibitory effect on cell proliferation of these compounds. These data are consistent with a role of the IGF system in stimulating the PC growth and the importance of IGF-I inhibition as an adjunctive mechanism of antineoplastic effect of somatostatin analogs.
These preclinical data notwithstanding, somatostatin analogues have shown a modest activity or no activity in PC patients with hormone refractory disease in few uncontrolled phase II trials. ${ }^{96-100}$ Since in these studies the primary aim was reduction in PSA serum levels or objective clinical response and not the time to progression, they cannot exclude a possible effect of these drugs in terms of prolongation of disease stabilization. Somatostatin analogs are long since recognized as the best antisecretory treatment of advanced well differentiated NE carcinomas. The antineoplastic effects of these drugs in these tumors, however, have been demonstrated only recently. In a randomized, placebo controlled, phase 2 study involving metastatic well-differentiated midgut carcinoma, in fact, octreotide administration was able to significantly prolong the time to progression despite a no-effect observed in terms of disease response. ${ }^{101}$

We conducted a small single institution prospective study in which PC patients with hormone refractory disease and NE differentiation received the somatostatin analog lanreotide. In this study lanreotide was able to significantly decrease the circulating levels of chromogranin A. ${ }^{102}$ Of course the changes of chromogranin A could not be considered a surrogate parameter of treatment efficacy, but these data provide the rationale of testing the efficacy of somatostatin analogs in prolonging the time to progression in a prospective randomized clinical trial in this patient subset.

Due to the poor expression of sst2 in patients with hormone naïve disease, ${ }^{103}$ no studies have tested the somatostatin analogs in addition to ADT in these patients. The availability in the near future of multireceptor ligand compounds with high affinity to somatostatin receptor subtypes sst1, sst2, sst3, and sst5 (such as pasireotide [SOM230]), ${ }^{104}$ will stimulate studies also in this subset.

Finally, as mentioned previously, the NE phenotype in PC patients is associated with a greater expression of the $\mathrm{PI} 3 \mathrm{~K} / \mathrm{AKT} / \mathrm{mTOR}$ pathway, providing a rationale for the use of mammalian target of rapamycin (mTOR) inhibitors. ${ }^{32}$ Rapamycin analogues are currently tested in PC patients with the aim to overcome the endocrine resistance. It would be interesting to know whether they are more active in the patient subset with NE differentiation.

\section{Conclusion}

The potential negative prognostic role of the coexistence of NE differentiation in the context of a predominant exocrine component of prostate adenocarcinoma is suggested by several preclinical observations and substantially confirmed by clinical data. The majority of clinical studies have, in fact, 
shown a significant correlation between NE differentiation and disease prognosis, and several studies have shown a tendency (not significant) toward this association. NE differentiation is not a stable phenotype, being stimulated by a variety of agents including commonly employed antineoplastic therapies. The proportion of PC patients with NE features, therefore, is destined to increase during the natural history of the disease.

The NE phenotype can be a pure prognostic parameter or influence the prognosis by favoring the onset of a castrate resistance status. It is actually not known which is the prevailing mechanism. Our personal experience is in favor of the second mechanism since the prognostic significance of this phenomenon in our series of patients was mainly confined to the patient subset who received ADT shortly after diagnosis as opposed to those who did not.

\section{Acknowledgment}

This study is supported in part by a grant of Regione Piemonte, Progetto Ricerca Finalizzata, March 2008.

\section{Disclosure}

The authors report no conflicts of interest in this work.

\section{References}

1. Di Sant'Agnese PA. Neuroendocrine differentiation in prostatic carcinoma: an update on recent developments. Ann Oncol. 2001;12 Suppl 2:S135-S140.

2. Vashchenko N, Abrahamsson PA. Neuroendocrine differentiation in prostate cancer: implications for new treatment modalities. Eur Urol. 2005;47(2):147-155.

3. Tricoli JV, Schoenfeldt M, Conley BA. Detection of prostate cancer and predicting progression: current and future diagnostic markers. Clin Cancer Res. 2004;10(12 Pt 1):3943-3953.

4. Bostwick DG, Dousa MK, Crawford BG, et al. Neuroendocrine differentiation in prostatic intraepithelial neoplasia and adenocarcinoma. Am J Surg Pathol. 1994;18(12):1240-1246.

5. Volante M, Rindi G, Papotti M. The grey zone between pure (neuro) endocrine and non-(neuro)endocrine tumours: a comment on concepts and classification of mixed exocrine-endocrine neoplasms. Virchows Arch. 2006;449(5):499-506.

6. Yuan TC, Veeramani S, Lin MF. Neuroendocrine-like prostate cancer cells: neuroendocrine transdifferentiation of prostate adenocarcinoma cells. Endocr Relat Cancer. 2007;14:531-547.

7. Huang J, Yao JL, di Sant'Agnese PA, Yang Q, Bourne PA, Na Y. Immunohistochemical characterization of neuroendocrine cells in prostate cancer. Prostate. 2006;66:1399-1406.

8. Van Bokhoven A, Varella-Garcia M, Korch C, et al. Molecular characterization of human prostate carcinoma cell lines. Prostate. 2003;57:205-225.

9. Segal NH, Cohen RJ, Haffejee Z, Savage N. BCL-2 proto-oncogene expression in prostate cancer and its relationship to the prostatic neuroendocrine cell. Arch Pathol Lab Med. 1994;118:616-618.

10. Slovin SF. Neuroendocrine differentiation in prostate cancer: a sheep in wolf 's clothing? [Review] Nat Clin Pract Urol. 2006;3(3):138-144.

11. Pearse AG, Takor T. Embryology of the diffuse neuroendocrine and its relationship to the common peptides. Fed Proc. 1979;38(9): 2288-2294.
12. Schron DS, Gipson T, Mendelsohn G. The histogenesis of small cell carcinoma of the prostate: an immunohistochemical study. Cancer. 1984;53:2478-2480.

13. Bonkhoff $\mathrm{H}$. Neuroendocrine cells in benign and malignant prostate tissue: morphogenesis, proliferation and androgen receptor status. Prostate Suppl. 1998;8:18-22.

14. Sauer CG, Roemer A, Grobholz R. Genetic analysis of neuroendocrine tumor cells in prostatic carcinoma. Prostate. 2006;66(3):227-234.

15. Palapattu GS, Wu C, Silvers CR, et al. Selective expression of CD 44, a putative prostate cancer stem cell marker, in neuroendocrine tumor cells of human prostate cancer. Prostate. 2009;69(7):787-798.

16. Deeble PD, Cox ME, Frierson HF, et al. Androgen independent growth and tumorigenesis of prostate cancer cells are enhanced by the presence of PKA-differentiated neuroendocrine cells. Cancer Res. 2007;67(8):3663-3672.

17. Spiotto MT, Chung TD. STAT3 mediates IL-6-induced neuroendocrine differentiation in prostate cancer cells. Prostate. 2000;42(3): 186-195.

18. Deeble PD, Murphy DJ, Parsons SJ, Cox ME. Interleukin-6-, cyclic AMP-mediated signalling potentiates neuroendocrine differentiation of LNCaP prostate tumor cells. Mol Cell Biol. 2001; 21(24):8471-8482.

19. Cox ME, Deeble PD, Bissonette EA, Parsons SJ. Activated 3', 5'-cyclic AMP-dependent protein kinase is sufficient to induce neuroendocrinelike differentiation of the $\mathrm{LNCaP}$ prostate tumor cell line. J Biol Chem. 2000;275(18):13812-13818.

20. Chen T, Cho RW, Stork PJ, Weber MJ. Elevation of cyclic adenosine 3',5'-monophosphate potentiates activation of mitogen-activated protein kinase by growth factors in $\mathrm{LNCaP}$ prostate cancer cells. Cancer Res. 1999;59(1):213-218.

21. Zelivianski S, Verni M, Moore C, Kondrikov D, Taylor R, Lin MF. Multipathways for transdifferentiation of human prostate cancer cells into neuroendocrine-like phenotype. Biochim Biophys Acta. 2001; 1539(1-2):28-43.

22. Pinski J, Wang Q, Quek ML, et al. Genistein-induced neuroendocrine differentiation of prostate cancer cells. Prostate. 2006;66(11): 1136-1143.

23. Diener KR, Need EF, Buchanan G, Hayball JD. TGF-beta signalling and immunity in prostate tumourigenesis. Expert Opin Ther Targets. 2010;14(2):179-192.

24. Jongsma J, Oomen MH, Noordzij MA, et al. Different profiles of neuroendocrine cell differentiation evolve in the PC-310 human prostate cancer model during long-term androgen deprivation. Prostate. 2002; 50(4):203-215.

25. Ahlgren G, Pedersen K, Lundberg S, Aus G, Hugosson J, Abrahamsson PA. Regressive changes and neuroendocrine differentiation in prostate cancer after neoadjuvant hormonal treatment. Prostate. 2000;42:274-279.

26. Berruti A, Mosca A, Tucci M, et al. Independent prognostic role of circulating chromogranin A in prostate cancer patients with hormonerefractory disease. Endocr Relat Cancer. 2005;12(1):109-117.

27. Sciarra A, Monti S, Gentile V, Mariotti G, et al. Variation in chromogranin A serum levels during intermittent versus continuous androgen deprivation therapy for prostate adenocarcinoma. Prostate. 2003;55(3):168-79.

28. Cheville JC, Tindall D, Boelter C, et al. Metastatic prostate carcinoma to bone: clinical and pathologic features associated with cancer-specific survival. Cancer. 2002;95:1028-1036.

29. Roudier MP, True LD, Higano CS, et al. Phenotypic heterogeneity of end-stage prostate carcinoma metastatic to bone. Hum Pathol. 2003;34(7):646-653.

30. Frković-Grazio S, Kraljić I, Trnski D, Tarle M. Immunohistochemical staining and serotest markers during development of a sarcomatoid and small cell prostate tumor. Anticancer Res. 1994;14(5B):2151-2156.

31. Vignani F, Russo L, Tucci M, et al. Why castration-resistant prostate cancer patients with neuroendocrine differentiation should be addressed to a cisplatin-based regimen. Ann Oncol. 2009;20(12):2019-2020. 
32. Deng X, Liu H, Huang $\mathrm{J}$, et al. Ionizing radiation induces prostate cancer neuroendocrine differentiation through interplay of CREB and ATF2: implications for disease progression. Cancer Res. 2008; 68(23):9663-9670.

33. Tang Y, Wang L, Goloubeva O, Khan MA, Lee D, Hussain A. The relationship of neuroendocrine carcinomas to anti-tumor therapies in TRAMP mice. Prostate. 2009;69(16):1763-1773.

34. Cox ME, Deeble PD, Lakhani S, Parsons SJ. Acquisition of neuroendocrine characteristics by prostate tumor cells is reversible: implications for prostate cancer progression. Cancer Res. 1999;59(15):3821-3830.

35. Wu C, Huang J. Phosphatidylinositol 3-kinase-AKT-mammalian target of rapamycin pathway is essential for neuroendocrine differentiation of prostate cancer. J Biol Chem. 2007;282(6):3571-3583.

36. Guillemot F, Lo LC, Johnson JE, et al. Mammalian achaete-scute homolog 1 is required for the early development of olfactory and autonomic neurons. Cell. 1993;75:463-476.

37. Borges M, Linnoila RI, van de Velde HJ, et al. An achaete-scute homologue essential for neuroendocrine differentiation in the lung. Nature. 1997;386:852-855.

38. Jiang SX, Kameya T, Asamura H, et al. hASH1 expression is closely correlated with endocrine phenotype and differentiation extent in pulmonary neuroendocrine tumors. Mod Pathol. 2004; 17:222-229.

39. Osada H, Tatematsu Y, Yatabe Y, et al. ASH1 gene is a specific therapeutic target for lung cancers with neuroendocrine features Cancer Res. 2005;65:10680-10685.

40. Shida T, Furuya M, Nikaido T, et al. Aberrant expression of human achaete-scute homologue gene 1 in the gastrointestinal euroendocrine carcinomas. Clin Cancer Res. 2005;11:450-458.

41. Rostomily RC, Bermingham-McDonogh O, Berger MS, et al. Expression of neurogenic basic helix-loop-helix genes in primitive neuroectodermal tumors. Cancer Res. 1997;57:3526-3531.

42. Ball DW, Azzoli CG, Baylin SB, et al. Identification of a human achaete-scute homolog highly expressed in neuroendocrine tumors. Proc Natl Acad Sci U S A. 1993;90:5648-5652.

43. Rapa I, Ceppi P, Bollito E, et al. Human ASH1 expression in prostate cancer with neuroendocrine differentation. Mod Pathol. 2008;21(6):700-707.

44. Mori R, Xiong S, Wang Q, et al. Gene profiling and pathway analysis of neuroendocrine transdifferentiated prostate cancer cells. Prostate. 2009;69(1):12-23.

45. Puccetti L, Supuran CT, Fasolo PP, et al. Skewing towards neuroendocrine phenotype in high grade or high stage androgen-responsive primary prostate cancer. Eur Urol. 2005;48(2):215-221.

46. Bollito E, Berruti A, Bellina M, et al. Relationship between neuroendocrine features and prognostic parameters in human prostate carcinoma. Ann Oncol. 2001;12 Suppl 2:S159-S164.

47. Ather MH, Abbas F, Faruqui N, Israr M, Pervez S. Correlation of three immunohistochemically detected markers of neuroendocrine differentiation with clinical predictors of disease progression in prostate cancer. BMC Urol. 2008;8:21.

48. McWilliam LJ, Manson C, George NJR. Neuroendocrine differentiation and prognosis in prostatic adenocarcinoma. Br J Urol. 1997;80: 287-290

49. Singh D, Febbo PG, Ross K, et al. Gene expression correlates of clinical prostate cancer behavior. Cancer Cell. 2002;1:203-209.

50. Tarle M, Ahel MZ, Kovacić K. Acquired neuroendocrine-positivity during maximal androgen blockade in prostate cancer patients. Anticancer Res. 2002;22(4):2525-2529.

51. Bonkhoff H, Wernert N, Dhom G, et al. Relation of endocrine-paracrine cells to cell proliferation in normal, hyperplastic and neoplastic human prostate. Prostate. 1991;19:91-98.

52. Bonkhoff $H$. Neuroendocrine differentiation in human prostate cancer. Morphogenesis, proliferation and androgen receptor status. Ann Oncol. 2001;12 Suppl 2:S141-S144.

53. Mazzucchelli R, Montironi R, Santinelli A, Lucarini G, Pugnaloni A, Biagini G. Vascular endothelial growth factor expression and capillary architecture in high-grade PIN and prostate cancer in untreated and androgen-ablated patients. Prostate. 2000;45(1):72-79.
54. Borre M, Nerstrom B, Overgaard J. Association between immunohistochemical expression of vascular endothelial growth factor (VEGF), VEGF-expressing neuroendocrine-differentiated tumor cells, and outcome in prostate cancer patients subjected to watchful waiting. Clin Cancer Res. 2000;6(5):1882-1890.

55. Partanen TA, Arola J, Saaristo A, et al. VEGF-C and VEGF-D expression in neuroendocrine cells and their receptor, VEGFR-3, in fenestrated blood vessels in human tissues. FASEB J. 2000;14(3):2087-2096.

56. Xing N, Qian J, Botswick D, Bergstralh E, Young CY. Neuroendocrine cells in human prostate over-express the anti-apoptosis protein survivin. Prostate. 2001;48:7-15.

57. Hirota K, Semenza GL. Regulation of angiogenesis by hypoxiainducible factor 1. Crit Rev Oncol Hematol. 2006;59(1):15-26.

58. McDonnell TJ, Troncoso P, Brishay SM, et al. Expression of the protooncogene bcl-2 in the prostate and its association with emergence of androgen-independent prostate cancer. Cancer Res. 1992; 52:6940-6944.

59. Abrahamsson PA, Waldstrom LB, Almmets J. Peptide-hormone and serotonin-immuno-reactive cells in normal and hyperplastic glands. Pathol Res Pract. 1986;181:675-683.

60. Nakada SY, Di Sant'Agnese PA, Moynes RA, Hiipakka RA, Cockett ATK, Abrahamsson PA. The androgen receptor status of neuroendocrine cells in human benign and malignant prostatic tissue. Cancer Res. 1993;53:1967-1970.

61. Scher HI, Sawyers CL. Biology of progressive, castration-resistant prostate cancer: directed therapies targeting the androgen receptor signaling axis. J Clin Oncol. 2005;23(32):8253-8261.

62. Jin RJ, Lho Y, Connelly L, et al. The nuclear factor-kappaB pathway controls the progression of prostate cancer to androgen-indipendent growth. Cancer Res. 2008;68(16):6762-6769.

63. Yang JC, Ok JH, Busby JE, Borowsky AD, Kung HJ, Evans CP. Aberrant activation of androgen receptor in new neuropeptide-autocrine model of androgen-insensitive prostate cancer. Cancer Res. 2009; 69(1):151-160.

64. Tarle M, Spajic B, Kraljic I, Kusic Z. Continuous finasteride therapy for benign prostate hypertrophy upgrades both neuroendorcine differentiation and aggressive prostate cancer. Anticancer Res. 2009;29(5): 1797-1801.

65. Thompson IM, Goodman PJ, Tangen CM, et al. The influence of finasteride on the development of prostate cancer. $N$ Engl J Med. 2003;349:216-224.

66. Redman MW, Tangen CM, Goodman PJ, Lucia MS, Coltman CA Jr, Thompson IM. Finasteride does not increase the risk of high-grade prostate cancer: a bias-adjusting modeling approach. Cancer Prev Res (Phila Pa). 2008;1(3):174-181.

67. Bass R, Perry B, Langenstroer P, et al. Effect of short-term finasteride on apoptotic factors and androgen receptors in prostate cancer cells. J Urol. 2009;181(2):615-619.

68. Kadmon D, Thomson TC, Lynch GR, Scardino PT. Elevated plasma chromogranin-A concentrations in prostatic carcinoma. J Urol. 1991; 146(2):358-361.

69. Cussenot O, Villette JM, Valeri A, et al. Plasma neuroendocrine markers in patients with benign prostatic hyperplasia and prostatic carcinoma. J Urol. 1996;155(4):1340-1343.

70. Berruti A, Dogliotti L, Mosca A, et al. Circulating neuroendocrine markers in patients with prostate carcinoma. Cancer. 2000;88(11):2590-2597.

71. Taplin ME, George DJ, Halabi S, et al. Prognostic significance of plasma chromogranin a levels in patients with hormone-refrectary prostate cancer treated in cancer and leukemia group B 9480 study. Urology. 2005;66(2):386-391.

72. Abrahamsson PA, Cockett ATK, di Sant'Agnese PA. Prognostic significance of neuroendocrine differentiation in clinically localized prostatic carcinoma. Prostate Suppl. 1998;8:37-42.

73. Ahlgren G, Pedersen K, Lundberg S, Aus G, Hugosson J, Abrahamsson PA. Neuroendocrine differentiation is not prognostic of failure after radical prostatectomy but correlates with tumor volume. Urol. 2000;56:1011-1015. 
74. Bostwick DG, Qian J, Pacelli A, Zincke H, Blute M. Neuroendocrine expression in node positive prostate cancer: correlation with systemic progaression and patient survival. J of Urol. 2002;168:1204-1211.

75. Bubendorf L, Sauter G, Moch H, et al. Ki67 labelling index: an independent predictor of progression in prostate cancer treated by radical prostatectomy. J Pathol. 1996;178:437-441.

76. Casella R, Bubendorf L, Sauter G, Moch H, Mihatsch MJ, Gasser TC. Focal neuroendocrine differentiation lacks prognostic significance in prostate core needle biopsies. J Urol. 1998;160:406-410.

77. Mc William LJ, Manson C, George NJR. Neuroendocrine differentiation and prognosis in prostatic adenocarcinoma. Br J Urol. 1997;80: 287-290.

78. Noordzij MA, Van der Kwast TH, Van Steenbrugge GJ, Hop WJC, Scröder FH. The prognostic influence of neuroendocrine cells in prostate cancer: results of a long-term follow up study with patients treated by radical prostatectomy. Int J Cancer. 1995;62:252-258.

79. Veltri RW, Isharwal S, Miller MC, et al. Long-term assessment of prostate cancer progression free survival: evaluation of pathological parameters, nuclear shape and molecular biomarkers of pathogenesis. Prostate. 2008;68:1806-1815.

80. Autorino R, Lamendola MG, De Luca G, et al. Neuroendocrine immunophenotype as predictor of clinical recurrence in 110 patients with prostate cancer. Int J Immunopathol Pharmacol. 2007;20:765-770.

81. Theodorescu D, Broder SR, Boyd JC, Mills SE, Frierson HF Jr. Cathepsin D and chromogranin A as predictors of long-term disease specific survival after radical prostatectomy for localized carcinoma of the prostate. Cancer. 1997;80:2109-2119.

82. Gunia S, Albrecht K, Koch S, et al. Ki67 staining index and neuroendocrine differentiation aggravate adverse prognostic parameters in prostate cancer and are characterized by negligible inter-observer variability. World J Urol. 2008;26:243-250.

83. Kamiya N, Suzuki H, Kawamura K, et al. Neuroendocrine differentiation in stage D2 prostate cancers. Int J Urol. 2008;15:423-428.

84. Krijnen JLM, Bogdanowicz JFAT, Seldenrijk CA, Mulder PGH, Van der Kwast TH. The prognostic value of neuroendocrine differentiation in adenocarcinoma of the prostate in relation to progression of disease after endocrine therapy. J Urol. 1997;158:171-174.

85. Lilleby W, Paus E, Skovlund E, Fosså SD. Prognostic value of neuroendocrine serum markers and PSA in irradiated patients with pN0 localized prostate cancer. Prostate. 2001;46:126-133.

86. Quek M, Daneshmand S, Rodrig S, et al. Prognostic significance of neuroendocrine expression in lymph node-positive prostate cancer. Urology. 2006;67:1247-1252.

87. Sciarra A, Gentile V, Autran Gomez AM, et al. Chromogranin A and biochemical progression-free survival in prostate adenocarcinomas submitted to radical prostatectomy. Endocr Relat Cancer. 2007; 14:625-632.

88. Yamada Y, Nakamura K, Aoki S, et al. An immunohistochemical study of chromogranin A and human epidermal growth factor-2 expression using initial prostate biopsy specimens from patients with bone metastatic prostate cancer. BJU Int. 2007; 99:185-195.

89. Weinstein MH, Partin AW, Veltri RW, Epstein JI. Neuroendocrine differentiation in prostate cancer: enhanced predictor of progression after radical prostatectomy. Hum Pathol. 1996;22:683-687.
90. Scher HI, Halabi S, Tannock I, et al. Design and endpoints of clinical trials for patients with progressive prostate cancer and castrate levels of testosterone: recommendations of the prostate cancer clinical trials working group. J Clin Oncol. 2008;26:1148-1159.

91. Berruti A, Mosca A, Porpiglia F, et al. Chromogranin A expression in patients with hormone naïve prostate cancer predicts the development of hormone refractory disease. J Urol. 2007;178:838-843.

92. Berruti A, Bollito E, Cracco C, et al. The prognostic role of immunohistochemical chromogranin A expression in prostate cancer patients is significantly modified by androgen-deprivation therapy. Prostate. 2009 [In press].

93. Brevini TA, Bianchi R, Motta M. Direct inhibitory effect of somatostatin on the growth of the human prostatic cancer cell line LNCaP: possible mechanism of action. J Clin Endocrinol Metab. 1993;77(3): 626-631.

94. Bogden AE, Taylor JE, Moreau JP, Coy DH, LePage DJ. Response of human lung tumor xenografts to treatment with a somatostatin analogue (Somatuline). Cancer Res. 1990;50(14):4360-4365.

95. Ruscica M, Arvigo M, Gatto F, et al. Regulation of prostate cancer cell proliferation by somatostatin receptor activation. Mol Cell Endocrinol. 2010;315:254-262.

96. Maulard C, Richaud P, Droz JP, Jessueld D, Dufour-Esquerré F, Housset M. Phase I-II study of the somatostatin analogue lanreotide in hormone-refractory prostate cancer. Cancer Chemother Pharmacol. 1995;36(3):259-262.

97. Kälkner KM, Acosta S, Thorsson O, et al. Octreotide scintigraphy and Chromogranin A do not predict clinical response in patients with octreotide acetate-treated hormone-refractory prostate cancer. Prostate Cancer Prostatic Dis. 2006;9(1):92-98.

98. Kälkner KM, Nilsson S, Westlin JE. [111In-DTPA-D-Phe1]-octreotide scintigraphy in patients with hormone-refractory prostatic adenocarcinoma can predict therapy outcome with octreotide treatment: a pilot study. Anticancer Res. 1998;18(1B):513-516.

99. Logothetis CJ, Hossan EA, Smith TL. SMS 201-995 in the treatmentof refractory prostatic cancer. Anticancer Res. 1994;14:2731-2734.

100. Figg WD, Thibault A, Cooper MR, et al. A phase I study of the somatostatin analogue somatuline in patients with metastatic hormonerefractory prostate cancer. Cancer. 1995;75:2159-2164.

101. Rinke A, Müller HH, Schade-Brittinger C, et al. Placebo-controlled, double-blind, prospective, randomized study on the effect of octreotide LAR in the control of tumor growth in patients with metastatic neuroendocrine midgut tumors: a report from the PROMID Study Group. J Clin Oncol. 2009;27(28):4656-4663.

102. Berruti A, Dogliotti L, Mosca A, et al. Effects of the somatostatin analog lanreotide on the circulating levels of chromogranin-A, prostate-specific antigen, and insulin-like growth factor-1 in advanced prostate cancer patients. Prostate. 2001;47(3):205-211.

103. Reubi JC, Schaer JC, Markwalder R, Waser B, Horisberger U, Laissue J. Distribution of somatostatin receptors in normal and neoplastic human tissues: recent advances and potential relevance. Yale J Biol Med. 1997;70(5-6):471-479.

104. Schmid HA. Pasireotide (SOM230): development, mechanism of action and potential applications. Mol Cell Endocrinol. 2008; 286(1-2):69-74.

Open Access Journal of Urology

\section{Publish your work in this journal}

The Open Access Journal of Urology is an international, peer-reviewed, open access journal publishing original research, reports, editorials, reviews and commentaries on all aspects of adult and pediatric urology in the clinic and laboratory including the following topics: Pathology, pathophysiology of urological disease; Investigation and treatment of

\section{Dovepress}

urological disease; Pharmacology of drugs used for the treatment of urological disease. The manuscript management system is completely online and includes a very quick and fair peer-review system, which is all easy to use. Visit http://www.dovepress.com/testimonials.php to read real quotes from published authors. 